\title{
Tanggung Jawab Developer Pada Perjanjian Pengikatan Jual Beli (PPJB) Perumahan Dalam Perspektif Hukum Perlindungan Konsumen
}

\author{
Hasyim Sofyan Lahilote
}

\begin{abstract}
Abstrak
Dalam perjanjian pengikatan jual beli perumahan, konsumen sering ditempatkan dalam posisi marginal sehingga kesepakatan yang berlaku sering merugikan pihak konsumen. Tanggung jawab developer dalam perjanjian tersebut habis setelah dirampungkannya pembuatan rumah yang dimaksud. Akan tetapi masalah mulai timbul bila spesifikasi rumah yang diperjanjikan tidak sesuai dengan apa yang diperjanjikan. Hukum perlindungan konsumen memberikan celah yang luas bagi konsumen untuk melindungi hak-hak hukumnya dalam perjanjian tersebut.
\end{abstract}

Kata kunci: perlindungan konsumen, developer, konsumen, hak-hak hukum.

\section{Pendahuluan}

Sejak zaman purba sampai dengan zaman modem saat ini, manusia membutuhkan rumah dan pemukiman sebagai tuntutan dasar manusia yang berbudaya, yang memiliki jati diri atau identitas hunian masing-masing. Sesederhana, apapun rumah yang dimiliki sesorang, bisa jadi merupakan sesuatu yang paling berharga, yang pernah dimilikinya sebagai tempat tinggal. Inilah yang menjadikan rumah sebagai hal yang mendasar dan juga menjadi prioritas utama dalam kodratnya sebagai makhluk sosial.

Sebelum terjadinya krisis moneter pada tahun 1997, minat masyarakat untuk memiliki rumah yang siap ditempati begitu besar. Hal ini dimanfaatkan dengan baik oleh para pengembang (developer) sebagai pelaku usaha di bidang perumahan, untuk meraup keuntungan yang sebesar-besarnya. Meskipun rumah yang ditawarkan masih belum jadi bahkan belum dibangun atau masih dalam tahap perencanaan, namun banyak diserbu konsumen oleh karena pemasaran yang begitu gencar oleh pihak pengembang.

Faktor-faktor inilah yang mengakibatkan perkembangan bisnis perumahan perlu mendapat perhatian khusus oleh pihak pemerintah untuk menjamin kepentingan rakyat banyak, karena yang menjadi sasaran dari pihak pengembang adalah masyarakat pada umumnya. Diharapkan juga terciptanya suatu hubungan bisnis dan hubungan hukum yang menguntungkan dan melindungi pihak pengembang sebagai pelaku usaha dan masyarakat sebagai konsumen, khususnya di bidang perumahan.

Pada kenyataannya, hanya pihak pengembang sebagai pelaku usaha saja yang memperoleh keuntungan dari bisnis jual beli rumah ini. Hal ini jelas-jelas terlihat atau dituangkan dalam Perjanjian Pengikatan Jual Beli (selanjutnya disebut PPJB) Perumahan, yang harus terlebih dahulu dilakukan sebelum melakukan perjanjian lainnya dalam proses jual beli perumahan. Padahal sesungguhnya kedua belah pihak, baik pengembang maupun konsumen mempunyai kedudukan yang sama di mata hukum. Untuk itu diperlukan perangkat hukum yang mengatur dan melindungi kepentingan 
konsumen dengan tidak mengabaikan kepentingan pihak pelaku usaha sehingga kepentingan keduanya terakomodir dalam perangkat hukum tersebut.

Perlindungan konsumen merupakan hal yang baru dalam peraturan perundang-undangan di Indonesia, yang timbul seiring dengan kebutuhan masyarakat akan hukum yang menurut mereka dapat melindungi dan memberi rasa aman seperti yang diamanatkan dalam pembukaan Undang-Undang Dasar (UUD) 1945 alinea keempat yaitu, kemudian daripada itu untuk membentuk suatu pemerintah negara Indonesia yang melindungi segenap bangsa Indonesia.

Dari kata melindungi terkandung asas perlindungan hukum bagi segenap bangsa tersebut. Segenap bangsa berarti tidak ada pengecualian di dalamnya. Perlindungan hukum bagi segenap bangsa juga berarti perlindungan yang tanpa terkecuali, baik dia laki-laki atau perempuan, orang kaya atau orang miskin, warga pribumi atau warga keturunan dan pengusaha atau konsumen. Dari hal di atas dapat diketahui bahwa hal yang menyangkut perlindungan konsumen adalah merupakan hak dari seluruh warga negara yang tidak pernah bisa berhenti menjadi kosumen sesuai dengan kodratnya sebagai makhluk sosial.

Dalam perkembangan selanjutnya dirasakan perlu untuk membuat suatu produk perundang-undangan yang secara khusus mengatur tentang perlindungan konsumen. Hal ini timbul karena banyaknya keluhan-keluhan dari pihak konsumen pengguna barang atau jasa yang dirugikan.

Di sisi lain, perlindungan pada kegiatan usaha tampaknya relatif lebih cepat disediakan. Tidak demikian halnya dengan peraturan mengenai perlindungan terhadap konsumen. Padahal sesungguhnya konsumen sama kedudukannya dengan pengusaha dan terutama sebagai penyerap hasil usaha kegiatan pengusaha tersebut.

Semacam sudah menjadi kebiasaan, mayoritas konsumen di Indonesia ketika berhadapan dengan pelaku usaha cenderung bersikap pasrah walaupun hak-haknya sebagai konsumen sudah diinjak-injak. Hal ini disebabkan oleh kurangnya pengetahuan masyarakat akan hak-haknya sebagai konsumen, sehingga sama sekali tidak ada, usaha untuk menuntut hak tersebut dan mengupayakan, posisi yang seimbang antara pelaku usaha dan konsumen. Konsumen pada umumnya baru berani berteriak, menulis surat pembaca di koran, ataupun melakukan hal yang lain apabila sudah mengalami penderitaan dan kerugian yang besar. Persepsi seperti inilah yang perlu diubah sehingga tercipta hubungan hukum yang sehat antara pelaku usaha dan konsumen.

\section{Pembahasan}

Salah satu instrumen perlindungan konsumen adalah perlindungan di bidang perumahan, karena kebutuhan akan rumah bagi seluruh lapisan masyarakat merupakan salah satu kebutuhan pokok yang harus dipenuhi dengan sebaik-baiknya. Dalam usaha jual beli rumah, pemasarannya menggunakan sarana iklan atau brosur untuk mengkomunikasikan produk-produk yang dibuat atau dipasarkan oleh pengembang, kepada konsumennya. Begitu gencarnya pemasaran, tak jarang informasi yang disampaikan itu ternyata tidak benar atau menyesatkan. Padahal konsumen sudah terlanjur menyetujui dan menandatangani Perjanjian Pengikatan Jual Beli (PPJB) dengan pengembang dan atau bahkan sudah mengambil Kredit Pemilikan Rumah (KPR) di bank. 
Masalah kemudian muncul jika pihak konsumen sudah menyetujui dan menandatangani PPJB, dan yang dilanjutkan dengan pembuatan akta jual beli rumah tersebut dihadapan notaris, kemudian apa yang ternyata diharapkan oleh konsumen mengenai janji-janji di brosur/iklan ternyata tidak dipenuhi oleh pelaku usaha. Sebagai contoh, di dalam iklan mengatakan bahwa perumahan yang dijanjikan tersebut memiliki fasilitas olahraga, tempat ibadah, dan juga sudah termasuk fasilitas listrik, telepon dan penyediaan air bersih, Tetapi dalam kenyataannya bukanlah demikian, Atau diiklankan oleh pelaku usaha bahwa daerah perumahan yang ditawarkan adalah daerah bebas banjir, tetapi setelah rumah tersebut dihuni beberapa lama, kemudian turun hujan deras dan ternyata perumahan tersebut mengalami kebanjiran. Belum lagi kondisi fisik rumah yang perbandingan campuran semennya tidak benar yang mengakibatkatan dinding dan lantai rumah pecah-pecah. Hal ini jelas-jelas merugikan konsumen.

Proses terjadinya kesepakatan antara pihak pengembang dan konsumen perumahan dituangkan dalam suatu bentuk perjanjian yang disebut Perjanjian Pengikatan Jual Beli (PPJB) atau nama lainnya bisa disebutkan seperti: Perjanjian Pendahuluan Pembelian, Perjanjian Akan Jual Beli, dan sebagainya. PPJB ini merupakan kesepakatan mula-mula antara pihak pengembang dan konsumen, yang di dalamnya berisi klausula-klausula menyangkut perjanjian kedua belah pihak. Pada kenyataannya PPJB ini disusun sepihak oleh pihak pengembang sebagai pelaku usaha yang tidak memungkinkan adanya perundingan atau negosiasi para pihak untuk menemukan suatu kesepakatan.

Dari segi hubungan hukum, adanya bentuk perjanjian yang hanya dibentuk oleh satu pihak saja dimaksudkan agar terciptanya kepraktisan serta penghematan waktu untuk menemukan kesepakatan para pihak dalam perjanjian tersebut. Dalam prakteknya telah disediakan formulir-formullir standar, jadi merupakan suatu perjanjian baku (standard contract).

\section{Tanggung Gugat Produk (Product Liability)}

Tanggung gugat produk adalah suatu istilah yang diterjemahkan dari bahasa Inggris yaitu product liability dan aansprakelikheid. Dalam terminologi hukum nasional doktrin product liability masih tergolong baru bahkan istilah tersebut mendapat terjemahan yang berbeda. Istilah product liability ada yang menerjemahkan sebagai tanggung gugat produk dan ada juga yang mengartikan sebagai tanggung jawab produk. ${ }^{1}$

Dalam Undang-undang No. 8 tahun 1999 tidak ditemukan definisi atau pengertian dari liability dimana dalam undang-undang tersebut liability diartikan sebagai tanggung jawab. Prinsip tanggung jawab dalam hukum perdata dapat digolongkan dalam dua jenis:

1. Kesalahan (liability besed on fault) pasal 1365 BW. Subjek pelaku kesalahan tersebut dapat bertanggung gugat berdasarkan doktrin hukum vicalovs liability dan corporate habilio).

2. Prinsip praduga untuk selalu bertanggung gugat (presumption of liability principle). Dalam prinsip ini tergugat selalu dianggap bertangung gugat sampai ia dapat membuktikan ia tidak bersalah (beban pembuktian pada si tergugat). ${ }^{2}$

\footnotetext{
${ }^{1}$ Gunawan Widjaya \& Ahmad Yani, Perlindungan Konsumen (Jakarta: Gramedia Pustaka Utama, 2000), h. 23.

${ }^{2}$ Ibid.
} 
Perhatian terhadap konsumen terutama, di Amerika Serikat (1960-an s/d 1970-an) mengalami perkembangan yang signifikan dan menjadi objek kajian di bidang ekonomi, sosial, politik dan hukum dimana pada era tahun-tahun tersebut berhasil diundangkan banyak sekali peraturan dan dijatuhkan putusan-putusan hakim yang memperkuat keadaan konsumen. Di Indonesia gerakan perlindungan konsumen menggema dari gerakan-gerakan serupa di Amerika Serikat.

Di Indonesia masalah perlindungan konsumen baru mulai terdengar pada tahun 1970-an, yang ditandai dengan lahirnya Yayasan Lembaga Konsumen Indonesia (YLKI) bulan Mei 1973.

Secara historis pada awalnya yayasan ini berkaitan dengan rasa mawas diri terhadap promosi untuk memperlancar barang-barang dalam negeri, dan atas desakan suara-suara masyarakat bahwa kegiatan promosi ini harus diimbangi dengan langkah-langkah pengawasan, agar masyarakat tidak dirugikan dan kualitasnya terjamin. Adanya keinginan masyarakat untuk melindungi dirinya dari barang yang rendah mutunya telah memacu untuk memikirkan secara sungguh-sungguh usaha untuk melindungi konsumen, dan mulailah gerakan untuk merealisasikan cita-cita itu.

Ditinjau dari kemajuan peraturan perundang-undangan di Indonesia mengenai perlindungan konsumen, sampai saat ini bisa dikatakan sangat minim, baik dilihat dari kuantitas peraturannya maupun kedalaman materi yang dicakupinya. Kenyataan tersebut memotivasi gerakan konsumen di Indonesia, termasuk yang diprakarsai oleh YLKI untuk membawa naskah akademik Undang-Undang Perlindungan Konsumen ke Dewan Perwakilan Rakyat.

Perkembangan baru di bidang perlindungan konsumen, yaitu tatkala Undang-Undang Nomor 8 Tahun 1999 Tentang Perlindungan Konsumen (UUPK) disahkan dan diundangkan pada 20 April 1999. UUPK ini masih memerlukan waktu satu tahun untuk berlaku efektif. Tanpa mengurangi penghargaan terhadap upaya terus menerus yang digalang YLKI, andil terbesar yang memaksa kehadiran UUPK adalah juga karena cukup kuatnya tekanan dari dunia internasional, dimana setelah pemerintah Republik Indonesia mengesahkan Undang-Undang nomor 7 Tahun 1994 tentang Agreement Estabilishing The World Trade Organization (Persetujuan Pembentukan Organisasi Perdagangan Dunia), maka ada kewajiban bagi Indonesia untuk mengikuti standar-standar hukum yang berlaku dan diterima luas oleh negara-negara anggota WTO. Salah satunya adalah perlunya eksistensi UUPK.

Istilah konsumen berasal dari kata consumer (lnggris-Amerika), atau Consument $l$ Konsument (Belanda). Pengertian dari consumer atau consument itu tergantung dalam posisi mana dia berada. Secara harfiah consmer itu adalah lawan dari produsen setiap orang yang menggunakan barang. Tujuan penggunaan barang atau jasa itu nanti menentukan termasuk konsumen kelompok mana pengguna tersebut. Begitu pula arti kata consumer "pemakai atau konsumen". ${ }^{3}$ Sedangkan menurut pasal I ayat 2 UUPK, konsumen adalah setiap orang pemakai barang dan/atau jasa yang tersedia dalam masyarakat, baik untuk kepentingan diri sendiri, keluarga, orang lain maupun makhluk hidup lain, dan tidak untuk diperdagangkan. Pada penjelasan pasal I ayat 2 UUPK tersebut dikatakan bahwa konsumen akhir adalah pengguna atau pemanfaat akhir suatu

\footnotetext{
${ }^{3}$ Sudaryatmo, Masalah Perlindungan Konsumen di Indonesia (Bandung: Citra Aditya Bhakti, 1996), h.
} 
produk, sedangkan konsumen antara adalah konsumen yang menggunakan suatu produk sebagai bahan dari proses produksi suatu produk lainnya. Pengertian konsumen dalam undang-undang ini adalah konsumen akhir.

Mantan Presiden Amerika Serikat, Jolin F. Kennedy, pernah mengemukakan empat hal dasar konsumen, yaitu :

1. Hak untuk mendapatkan keamanan (fhe right to safety)

2. Hak untuk mendapatkan informasi (The right to be informed)

3. Hak untuk memilih (fhc right to choose)

4. Hak untuk didengar (The right to be heard). ${ }^{4}$

Empat hal dasar ini diakui secara intemasional. Dalam perkembangannya, organisasi-organisasi konsumen yang tergabung dalam The International Orgaization of Consumers lInjon (IOCV) menambahkan lagi beberapa hak, seperti hak mendapatkan pendidikan konsumen, hak mendapatkan ganti kerugian, dan hak mendapatkan lingkungan hidup yang baik dan sehat.

Dari keempat hak pokok diatas keamanan konsumen merupakan hal yang paling pokok dan utama dalam perlindungan konsumen. Barang dan/atau jasa yang dalam penggunaannya tidak memberikan kenyamanan, terlebih lagi yang tidak aman atau membahayakan keselamatan konsumen jelas tidak layak untuk diedarkan dalam masyarakat. Selanjutaya untuk menjamin bahwa suatu barang dan/atau jasa dalam penggunaannya akan nyaman, aman, dan tidak membahayakan konsumen penggunanya, maka konsumen diberikan hak untuk memilih barang dan/atau jasa yang dikehendakinya berdasrkan atas keterbukaan informasi yang benar, jelas dan jujur. Jika terdapat penyimpangan yang merugikan, konsumen berhak untuk didengar, memperoleh advokasi, pembinaan, perlakuan yang adil, kompensasi, sampai ganti rugi.

Selain memiliki hak-hak yang diatur dalam pasal 14 UUPK konsumen juga mempunyai kewajiban yang harus dipenuhi yang dijelaskan dalam pasal 5 UUPK sebagai berikut :

a. Membaca atau mengikuti petunjuk informasi dan prosedur pemakaian atau pemanfaatan barang dan/atau jasa demi keamanan dan keselamatan;

b. Beritikad baik dalam melakukan transaksi pembelian barang dan/atau jasa;

c. Membayar sesuai dengan nilai tukar yang disepakati;

d. Mengikuti upaya penyelesaian hukum sengketa perlindungan konsumen secara patut.

Hal ini dimaksudkan agar tercipta suatu hubungan hukum yang sehat antara pihak konsumen maupun pelaku usaha.

\section{Perjanjian}

\section{a. Pengertaian Perjanjian Pada Umumnya}

Dalam pasal 1313 KUH Perdata mendefinisikan perjanjian adalah "suatu perbuatan dimana satu orang atau lebih mengikatkan diri pada satu orang atau lebih". Selanjutnya Subekti mengatakan bahwa suatu perjanjian adalah suatu peristiwa dimana seorang berjanji pada seorang yang lain atau dimana dua orang itu saling berjanji untuk melaksanakan sesuatu hal. ${ }^{5}$

\footnotetext{
${ }^{4}$ Ibid.

${ }^{5}$ R. Subekti, Hukum Perjanjian (Jakarta: Intermasa, 1986)
} 
Perjanjian merupakan sumber terpenting yang melahirkan perikatan. Memang perikatan itu paling banyak diterbitkan oleh suatu perjanjian, tetapi sebagaimana dikatakan tadi, ada juga sumber-sumber lain yang melahirkan perikatan. Sumber-sumber lain ini tercakup dengan nama undang-undang. Jadi, ada perikatan yang lahir dari perjanjian dan ada perikatan yang lahir dari undang- undang. ${ }^{6}$

Kemudian agar bisa dikatakan bahwa perjanjian itu sah, maka hal ini harus sesuai dengan apa yang termuat dalam pasal 1320 KUHPerdata, yang mengatakan bahwa untuk sahnya suatu perjanjian diperlukan 4 (empat) syarat, yaitu :

1. Kesepakatan mereka yang mengikatkan dirinya.

2. Kecakapan untuk membuat suatu perjanjian.

3. Mengenai suatu hal tertentu.

4. Suatu sebab yang tidak terlarang.

\section{b. Perjanjian Pengikatan Jual Beli (PPJB) Perumahan}

Bila membeli rumah atau rumah susun, seorang konsumen pasti akan menjumpai dokumen-dokumen hukum (legal documents) yang penting yaitu :

1. Perjanjian Pengikatan Jual Beli, disingkat (PPJB), atau nama lainnya seperti: Perjanjian Pendahuluan Pembelian, Perjanjian Akan Jual Beli antara pengembang dan konsumen.

2. Akta Jual Beli yang dibuat dan ditandatangani dihadapan Pejabat Pembuat Akta Tanah (PPAT) untuk mengalihkan atau memecah pemilikan tanah dan rumah dari pengembang kepada setiap konsumen.

3. Perjanjian Kredit Pemilikan Rumah dari bank pemberi KPR. ${ }^{7}$

Dokumen yang pertama merupakan dokumen yang membuktikan adanya hubungan hukum (hubungan kontraktual) antara pengembang dan konsumen, dimana pengembang mengikatkan diri untuk menjual rumah dan tanah kepada konsumen, sedangkan konsumen membeli rumah dari pengembang dengan kewajiban membayar harga jualnya dalam bentuk angsuran uang muka (Down Payment) dan sisanya diselesaikan dengan fasilitas KPR.

Dokumen yang kedua terjadi sebagai akibat dari terciptanya kata sepakat pada Perjanjian Pengikatan Jual Beli (PPJB). Kalau pada dokumen pertama hanya dimaksudkan untuk mengikat perjanjian antara pihak pengembang dan konsumen dalam melakukan kewajibannya masing-masing sebagaimana yang tertuang dalam PPJB tadi, maka dokumen yang kedua adalah realisasi dari apa yang diperjanjikan dalam PPJB tadi.

Sedangkan dokumen yang ketiga menunjukkan adanya hubungan hukum antara konsumen dengan pihak bank pemberi KPR. Di dalamnya antara lain diatur jumlah pinjaman, jangka waktu pelunasan KPR, besarnya atau sistem perhitungan bunga pinjaman. Sebagaiman lazimnya pada setiap pembuatan perjanjian yang semata-mata berlandaskan pada asas kebebasan berkontrak, maka juga pada PPJB masing masing pihak berusaha untuk menciptakan dominasi pada pihak lainnya.

\footnotetext{
${ }^{6}$ Ibid.

${ }^{7}$ Yusuf Shofie, Perlindungan Konsumen dan Instrumen - Instrumen Hukumnya (Bandung: Citra Aditya Bakti, 2000).
} 
Dalam kenyataannya, PPJB ini hanya disusun secara sepihak oleh pengembang sehingga tidak ada kemungkinan bagi konsumen untuk bernegosiasi tentang isi perjanjian ini. Perjanjian yang hanya disusun oleh salah satu pihak saja selanjutnya lebih populer dengan nama perjanjian baku (standard contract).

Perjanjian baku ini banyak sekali dipakai dalam berbagai macam perjajian di lapangan dunia usaha. Karena sifatnya yang praktis, jenis perjanjian ini banyak sekali disukai para pelaku usaha diberbagai bidang, baik di bidang perumahan, jasa perbankan, perdagangan, asuransi, dll untuk lebih mensinergikan kegiatan usaha yang bersifat mudah sehingga dapat menghemat waktu dan biaya yang mungkin akan timbul bila kita menggunakan jenis perjanjian yang dikehendaki oleh KUHPerdata. Sebab di dalam perjanjian baku ini konsumen tinggal menandatangani akta perjanjian atau menerima begitu saja nota jual beli tanpa mengadakan negosiasi antara penjual dan pembeli sebagaimana yang diamanatkan oleh KUHPerdata sehingga dikemudian hari apabila timbul wanprestasi dari pihak pelaku usaha, posisi konsumen untuk mengadakan klaim kerugian kepada pelaku usaha berada pada posisi yang sangat lemah karena telah menandatanagani surat perjanjian tersebut atau telah menerima nota jual beli tersebut. sehingga bila terjadi sengketa di pengadilan nanti, konsumen tersebut akan dikalahkan oleh para pelaku usaha karena mereka mempunyai bukti yang cukup kuat yang ditandatangani oleh konsumen tersebut.

Dengan adanya undang-undang nomor 8 tahun 1999 tentang Perlindungan Konsumen yang secara substantif telah dapat mengakomodasi kepentingan para konsumen diseluruh Indonesia, diharapkan praktek-praktek seperti yang telah tersebut di atas dapat dihilangkan dalam dunia perdagangan atau paling tidak dapat diminimalisasi keadaannya sehingga nantinya klaim-klaim kerugian yang diakibatkan oleh praktek perjanjian baku dapat dihilangkan sehingga tercipta iklim usaha kondusif yang menguntungkan kedua belah pihak, baik para pelaku usaha dalam hal ini pengembang maupun para konsumen.

\section{Penutup}

Dengan adanya pengesahan Undang-Undang Nomor 7 Tahun 1994 tentang Agreement Estabilishing The World Trade Organization (Persetujuan Pembentukan Organisasi Perdagangan Dunia), maka negara Indonesia mempunyai kewajiban untuk mengikuti standar-standar hukum yang berlaku dan diterima luas oleh negara-negara anggota WTO.

Akibat dari adanya pengesahan undang-undang tersebut ditetapkanlah Undang-Undang Nomor 8 Tahun 1999 tentang Perlindungan Konsumen (UUPK) yang secara substantif bertujuan untuk melindungi kepentingan konsumen dalam dunia perdagangan.

Dengan adanya UUPK ini, para konsumen dapat menuntut klaim kerugian kepada para pelaku usaha sepanjang apa yang diperjanjikan dalam kontrak tersebut tidak dipenuhi oleh pelaku usaha.

Dengan adanya UUPK ini Para pelaku usaha, khususnya para pengembang (developer) perumahan, disyaratkan tidak lagi menerapkan sistim perjanjian baku (standard contract) yang pada prinsipnya banyak merugikan para konsumen dalam dunia perdagangan. 
Pengembang (developer) perumahan harus bertanggung jawab terhadap berbagai klaim kerugian yang ditimpakan kepadanya oleh para konsumen bila terjadi wanprestasi terhadap kontrak yang telah disepakati bersama.

\section{Daftar Pustaka}

Gunawan Widjaya \& Ahmad Yani, Perlindungan Konsumen (Jakarta: Gramedia Pustaka Utama, 2000).

Shofie, Yusuf, Perlindungan Konsumen dan Instrumen-Instrumen Hukumnya (Bandung: Citra Aditya Bakti, 2000).

Sudaryatmo, Masalah perlindungan konsumen di Indonesia (Bandung: Citra Aditya Bhakti, 1996).

Subekti, R. Hukum Perjanjian (Jakarta: Intermasa, 1986).

Undang-Undang Nomor 8 Tahun 1999 tentang Perlindungan Konsumen.

Kitab Undang-Undang Hukum Perdata. 